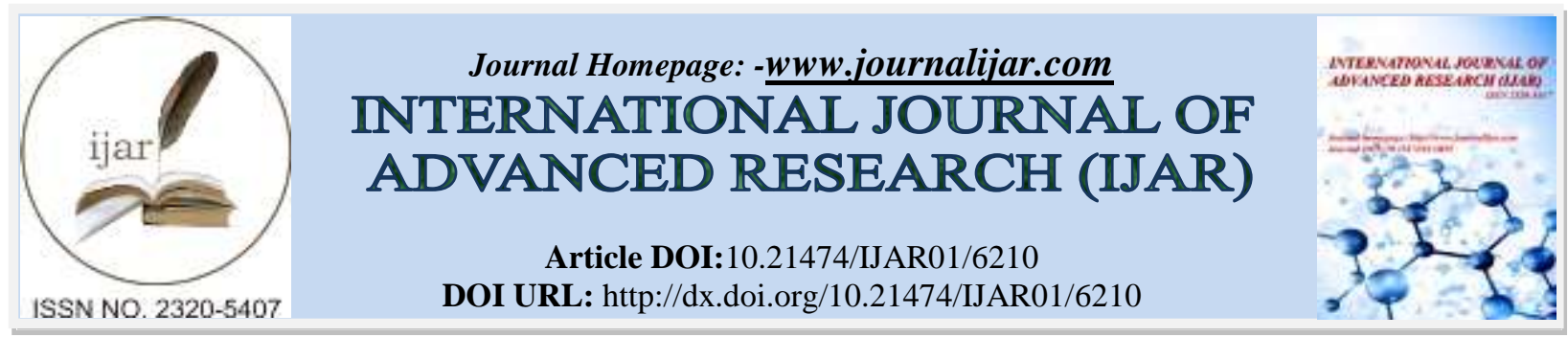

RESEARCH ARTICLE

\title{
EFFORT TO OVERCOME PIRACY IN THE INDONESIA-PHILIPPINES MARITIME BORDERS.
}

\author{
Dr. Surya Wiranto, SH., MH. \\ A retired Indonesian Army General-TNI Laksda (Purn.); Lecturer in Maritime Security at Universitas Pertahanan \\ (the University of Defense) Jakarta-Indonesia.
}

\section{Manuscript Info}

Manuscript History

Received: 04 November 2017

Final Accepted: 06 December 2017

Published: January 2018

Key words:-

Piracy, Bilateral, Cooperation, International Law, Maritime Border.

\begin{abstract}
As a country which share her maritime borders with ten other countries, and one of them is the Philippines, it is pretty certain that Indonesia must also shares the burden with the Philippines in order to make sure that the border waters areas, especially the Indonesia-Philipine one which is intensified with the the threat of transnational crime and varied in their forms and types are save to sail. Although it has been described that so far the two countries have been involved in a bilateral cooperation to maintain the security and peace in the water border areas, to date the maritime border between Indonesia and the Philippines in the Sulawesi Sea and Talaud waters have not yet fully been reached by the agreement or the nilateral cooperation. This has creating one of the constraints of law enforcement on some form of breach of the international law in the region. There still been going on criminal activities such as illegal fishing in the Sulawesi Sea, as this Indonesia's waters area is the main pulling factor for such an activity, since it contain with a rich natural resources (fisheries) in large quantities. There has also been many illegal entries by both ordinary citizens and by a terrorist syndicate that utilizes ships routinely crossing the two countries sharing waters border of the region. There is a need for a strengthening the capacity and amount of the KRI involved in Patkor Philindo and Malphindo (if it has been formed) adapted to the area of operation, where the Indonesian-Philippines frontier of approximately $600 \mathrm{Nm}$ requires the ideal number of warships as many as seven warships as well as the duration of time in that Patkor is a year-round in order to minimize breaches of the international law at sea.
\end{abstract}

Copy Right, IJAR, 2018,. All rights reserved.

\section{Introduction:-}

Indonesia has a very strategic geographic position. She shares waters or maritime areas which border with other countries. One of the areas is Sibutu Sailing Channel. This Channel is a shared water borderline areas between the Philippines and Malaysia but it also adjacent to the Indonesian territorial waters. Therefore this Channel is attributed as an Indonesia-Malaysia-Philippines shared waters border. It has been used as well, as the sailing route leading to or from Makasar Strait (ALKI 2). ${ }^{1}$

\footnotetext{
${ }^{1}$ ALKI-II is the Indonesian Archipelago Sea Lane -II. It is located in central Indonesia.
} 
At this Channel ships have been sailing through from or to the what so called ALKI 2. Since the position of the strait is also located in between the Sulu Islands, Tawi-Tawi Island, Jolo Island and Basilan Island. All of these three silands has been used by the Abu Sayyaf group for the base for their activities.

As a country which share her maritime borders with ten other countries, and one of them that has been mentioned above is the Philippines, it is pretty certain that Indonesia must also shares the burden with the Philippines in order to make sure that the border waters areas, especially the Indonesia-Philipine one which is intensified with the the threat of transnational crime and varied in their forms and types are save to sail.

There have been eight types of transnational crimes being identified namely: drugs trade (narcotics), human trafficking, piracy or sea robbery, arms smuggling, money laundering, terrorism, international economic crimes, and cyber-crime in this waters border or maritime area. From the International Law's perspective, in order to tackle these form of transnational crimes Indonesia needs to cooperate both bilaterally and multilaterally with other countries.

Among the other crimes listed above, the criminal act of pirating ships passing through the Indonesia-Philippines border waters conducted by the Abu Sayyaf Group (ASG) is predicted will continue to persist. As this ASG has been supported through, and most likely deeply depending on the piracy and ships crew hijacking fund-raising activities. As it (the ASG) has been internationally notorious for their asking for a ransom from flagship countries in returned for the ships crew released from their hands. In other words if if their request is not met, and the ransom required is failed to be paid by the flagships countries the Abu Sayyaf group will beheading all the held hostage, even though those include in the hostage were their own citizens, the ships crew (ABK), tourists, foreign workers, etc.). The ASG has been using this criminal war strategy as one of their efforts to pressure the Philippines government and the international community that the existence of the Abu Sayyaf group needs to be taken into account. As it has been internationally known the main purpose of the ASG has been to establish an Islamic state in the Sulu archipelago. This criminal war strategy, such us piracy and hijacking for ransom has been very disturbing for the security of ships passing through the three state borders and potentially destabilize the region. ${ }^{2}$

In solving the problem of piracy and hostage taking in the waters of Sulu, especially the eruption and hostage taking on Indonesian-flagged vessels and crew, it is necessary to cooperate between Indonesia and the Philippines and engage the military of both countries into this cooperation. The cooperation could be made directly or indirectly, depend on the nature of piracy prevention between Indonesia-the Philippines. So far a Coordinated Patrol of the Philippines-Indonesia (PatkorPhilindo) has been implemented by the Navy and Republic Philipine Navy/RPN in the sea border waters of both countries. This coordination has been aimed at ensuring the save and security at the sea border of each country. The Coordinated Programme (Patkor) has been conducted temporarily and only one time in a year with duration of 20 days.

Although this initial and important international cooperation between Indonesia and the Philippines have not yet having a Standard Operating Procedures (SOP). It has been felt that this SOP could be the field and operating guidance for in in executing the Patkor. For Indonesia one legal basis that underlying the Patkor's cooperation is the Law of the Republic of Indonesia Number 20 Year 2007 dated April 10. This Law has been made to legalizing the Cooperation within an international law framework named the agreement between the Government of the Republic of Indonesia and the Government of the Republic of the Philippines on Cooperation Activities in Field of Defense and Security.

\section{Indonesia-Philippines Maritime Border Situation:-}

The maritime border situation between the Philippines and Indonesia could be coined as very vulnerable. Particularly in the Sulu (consists of the island of Tawi-Tawi, Jolo and Basilan). As briefly mentioned above within these three islands, of which waters or maritime area share the maritime border of the Indonesia and the Philippines there are base camps of the ASG.

Just to mentioned briefly, the ASG A is a Muslim radical groups in the Philippines. This group has been undertaking many terror threats for the people of Philippines. The Philippines government has not only been facing this

\footnotetext{
${ }^{2}$ Surya Wiranto, Pembajakan dan Penyanderaan, Tantangan bagi Pelaut Indonesia, Maritime News, 12 Juli 2016.
} 
particular Muslim radical group which come from the Abu Sayyaf group. It has also been engage with the violence threats from other radical Islamic groups within the Philippines called the MILF (Moro Islamic Liberation Front). There has also been other radical Muslim group within the Philippines which is named as the MNLF (Moro National Liberation Front ).

Figure 1:- Map of Border Situation of the Indonesia-Philippines

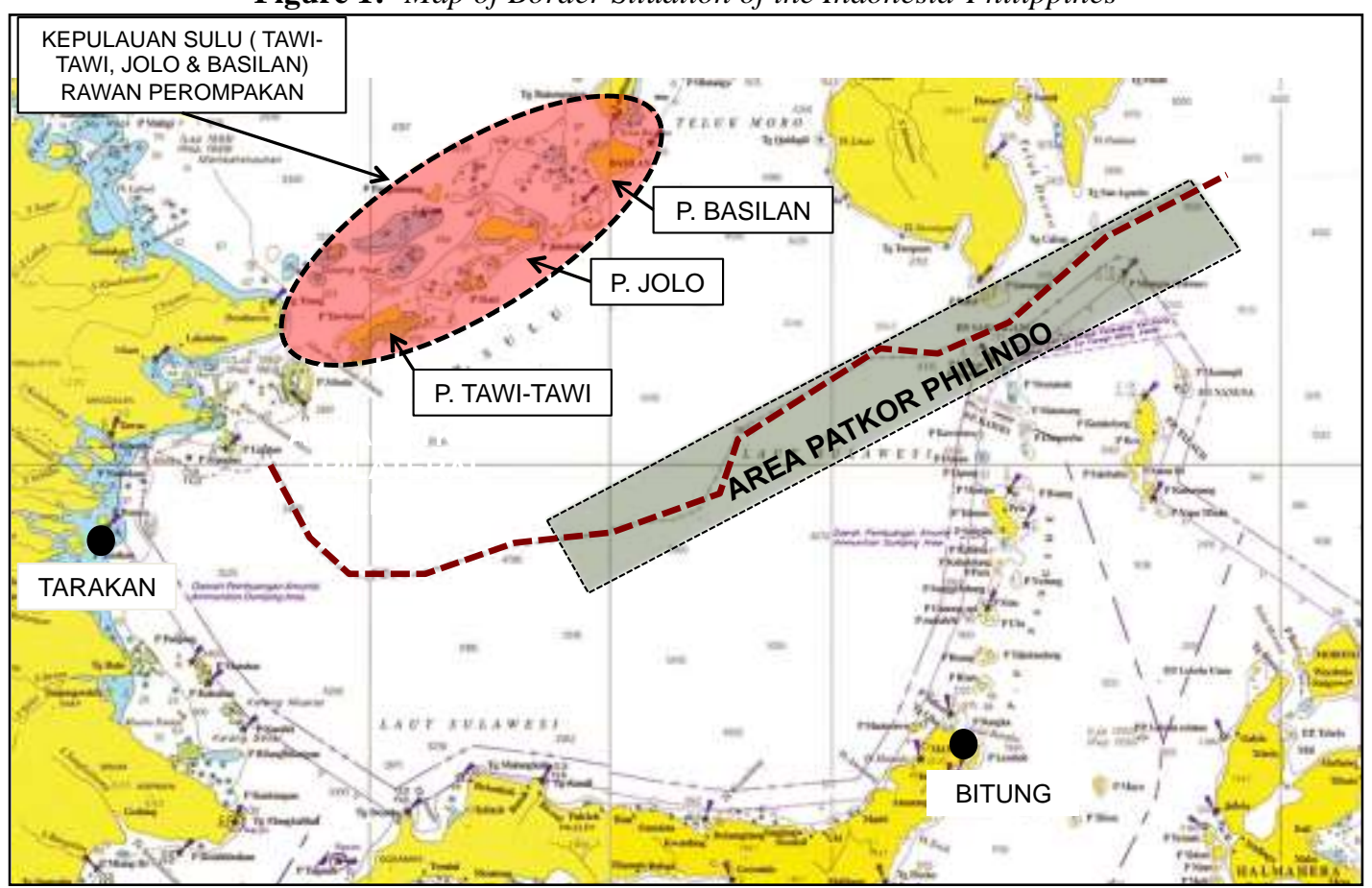

Source: Made by this Author, 2017

Responding to the security situation in the maritime border of the two countries, especially in Miangas iland, Marore island and the outer islands surrounding Mindanao, the Indonesia National Army (The TNI/Navy cooperate with the Republic of Philippines Navy to hold a coordinated patrol. This activity has been considered as an effort undertaking in order to maintain the security in the territorial waters of the national jurisdiction of the territorial sea of IndonesiaPhilippines against any violation of territory and crime.

Although it has been described above that so far the two countries have been involved in a bilateral cooperation to maintain the security and peace in areas as mentioned above, to date the maritime border between Indonesia and the Philippines in the Sulawesi Sea and Talaud waters have not yet fully been reached by the agreement or the bilateral cooperation. This has creating one of the Const- 
Figure 2:- The ASG Dominated Held Islands

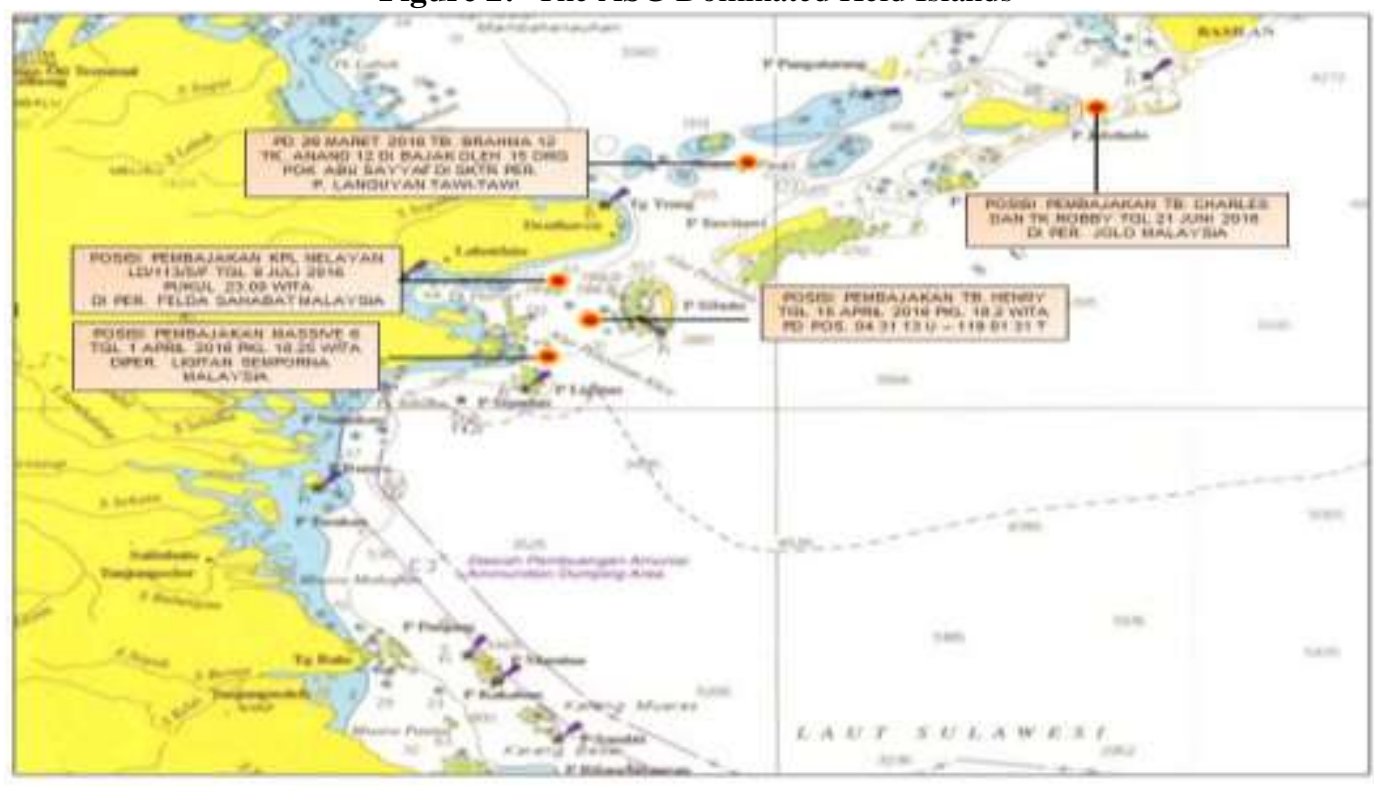

strains of law enforcement on some form of breach of the international law in the region. There still been going on criminal activities such as illegal fishing in the Sulawesi Sea, as this Indonesia's waters area is the main pulling factor for such an activity, since it contain with a rich natural resources (fisheries) in large quantities. There has also been many illegal entries by both ordinary citizens and by a terrorist syndicate that utilizes ships routinely crossing the two countries sharing waters border of the region.

3. Piracy at the Shared Sea Borders Areas of the Philippines-Indonesia;-

It has been briefly mentioned above that the ASG is an Islamic militant group that has terrorized the South Philippines with piracy since the 1990s. The impact of these violent activities have greatly affected the stability of the security of the Southeast Asian region, particularly Indonesia. Data from various sources mention some of the crimes and criminal activities committed by the ASG.

Among others ${ }^{3}$ are: (a). In March 20, 2016 held 10 hostage of the crew of the TB. Brahma 12 and TK Anand 12, two of the Indonesia flagged ship. All the crew were the Indonesian citizen; (b). In April 1, 2016 against TB. Massive 6, a Malaysian flagged ship. It was hijacked, and the crew was held hostage in the waters of Ligitan Samporan Island Sabah-Malaysia nearby the South Fhilipina. (c). On April 15, 2016, there was an act of piracy of TB Henry ship and TK Christy, two of the Indonesian flag ship at the Malaysia-Philippines border waters, the vessel was traveling from Cebu Philippines to Tarakan. (d). In June 18, 2016 TB. Charles and TK Robby 152, again two of the Indonesian flagship was hijacked when it was taking sail from Jagayan Gracia Port Philippines to Samarinda. The hijackers taking seven hostage, all are crew of Indonesian Citizen. (e). In July 09, 2016 there was a hostage taking of 3 Indonesian crew members working on Malaysian LD/113/5/F fishing vessel in Per. Felda Sahabat Malaysia.

\section{Philindo Indonesia-Philippines Border Waters Anti-Piracy Patrol;-}

Valuing the Patkor Philindo between Indonesia and the Philippines, it could be argue that the bilateral undertaking has been so far worked well; although there are some things that still need improving, however. It could be fairly sated that the Patkor Philindo has been held every year in accordance with the planning. The framework of Patkor has been running according to the bilateral international agreement of the RIPHBC (Republic Indonesia-Philpina Border Committee). There has also been many other improving went well. Therefore this international law instrument has not only strengthening the cooperation but also the relationships between Indonesia and the Philippines as a two neighboring countries, especially navy to navy. To realize its objectives its implementation must be in a state of continuing evaluation and, these activities must be communicated between the two Navy.

${ }^{3}$ EndraKusuma, ST, LetkolLaut (P) Nrp 13280/P, Indonesian Liaison Officer di Philipina, 2016. 
Aspects that need to be improved are both in terms of operating time, the operating area that reaches along the sea border between the two countries and increasing the degree element- the element Patkor Philindo. It needs to involve two Military Command of the Philippines namely Western Mindanao Command (Given that the Patkor Philindo has been so far to includes Eastmincom only). It is also important to consider that the Patkor Philindo is to be implemented every year. In addition to tackling various abuses in the sea ranging from illegal fishing, illegal entry, weapons smuggling and other sea abuses, it should also engage in enhance the friendship of both countries. To improve the ability of the Patkor Philindo to be able to tackling off the piracy in the vicinity of the Sulu Islands waters. Therefore its operation area must be enhanced to cover the waters of the Sulu archipelago which is the sovereign territory of the Philippines.

Patkor Philindo which is part of defense cooperation between Indonesia-Philippines that has been implemented in Indonesia-Philippines waters border still struggling with some deficiencies that must immediately reformed, especially in overcoming piracy in the waters borders of Tawi Island, Sulu Island and Basilan Island. All of these additional or improving plan must be formulated upon an international law umbrella in order to have an international law justification to combat piracy together in the waters around the Sulu archipelago.

Based on some of the theories related to Cooperation between TNI and Military of the Philippines in overcoming piracy, there are several aspects that have to be put into consideration in increasing cooperation such as Legal Aspects, Alutsista, Personnel, Pangkalan (base), Operation Area and SOP. These improving aspects is described below.

\section{a. Legal Aspects.}

According to United Nations On The Law of the Sea of 1982 (UNCLOS 1982), there have been mentioned things on obligations for cooperation within suppression of piracy at sea. It is stipulated in the Article 100 of UNCLOS. It is read that all countries must cooperate fully in the repression of piracy on the high seas in any other place outside its jurisdiction.

The article of 100 as mentioned above has dictate that the cooperation of suppression of piracy in the open seas and outside the jurisdiction of a state is an obligation of every country. However, if the piracy take place within its jurisdiction, its the suppression of piracy in the jurisdiction of a state is the responsibility of the country itself. Therefore, with regards to the suppression of any piracy in the Philippines, it is the Philippines that has the full international law. But in view of the victims of piracy or hostage of Indonesian citizens, to protect their citizens the Indonesian government is obliged to make efforts to free the hostages in cooperation with the Philippines government.

In relation to that, it has been stated in the Article 107 of UNCLOS that an act of confiscation or a foreclosure because of piracy may only be carried out by warships or military aircraft, or a ship or aircraft that is clearly marked and identifiable as being on government service and authorized to do so. The article implies that any action against piracy must use military warships or aircraft, or other ships or aircraft clearly marked and recognized as government services and authorized to do so. A departing of the international law requirement, in relation to the "Sea Marshall" by the Military, has not a strong foundation to be implemented, which may be implemented is escorting using the Warship even if there is agreement or agreement between countries.

The acts of piracy perpetrated by the ASG are compatible with the theory proposed by Sir Charles Hedges, a British judge, in 1600) in a case tried by the British Cruise Court. Hedges argued that that pirates are robbers who seized the vessel and/or cargo through the hard way in the ocean. This British rule might be used by the Philippines and Indonesia, as a juridical basis for their international cooperation more broadly in overcoming piracy crimes perpetrated by the terrorist group such as the ASG. The cooperation needs to be improved, ranging from preventive measures through the Coordinated Patrol around the border waters near the waters of Tawi- tawi, Jolo Island and Basila Island.

However, the ability to overcome the crime of piracy could be improved from merely a bilateral cooperation, as between Indonesia-Philipina to a trilateral, or perhaps multilateral cooperation by involving other countries, and in this case Malaysia in conducting coordinated Patrol. Since the locus delicti of piracy incident is at around TawiTawi island, Jolo Island and Basilan Island. These islands are having a very close and bordering with the territorial waters of Malaysia. 
Apart from the theory stated above, in accordance with a terrorism theory defined by the US Department of Defense, terrorism is politically motivated violence perpetrated by state agents or sub-national groups against combatant groups. When linked with terrorism theory, the crime of piracy committed by the ASG which is part of a group in the Philippines with its actions that rob and hijack ships and citizens of Indonesia, the impact of which affect on the regional and even on the global stability. Therefore, if Indonesia and the Philippines cooperate bilaterally in overcoming piracy around the border, it will have only a limited political impact for both countries that are jointly able to overcome the terrorism that became a global enemy. It needs to furtherance the scale of cooperation into a multilateral scale.

\section{b. The Weapon and Related Supported (Alutsista) Aspects.}

On the basis of these considerations, the authors carry out research and use several theories as a reference, among others, Piracy Theory. With the piracy carried out by the ASG by taking away valuables, taking crew as hostage or captives and asking for money as ransom, then the action of this group belongs to the category of Major Criminal Hijack. The ASG was also included into the category terrorism. According to terrorism throry, as mentioned above, terrorism is the politically motivated violence perpetrated by state agents or sub-national groups against noncombatant groups. The ASG action is considered as terrorism since it involves citizens or territories of more than one country.

In connection with the theory of Regional Security Stability proposed by Bantarto Bandoro that the domestic instability of a country will lead to regional disputes. This theory will have justified efforts to improve the capability of Indonesia and the Philippines. So they will be expand the weapon and related supported military and security instrument (Alutsista), such as War Ships involved in the overcoming of piracy in the border waters, and strengthening the achievement of regional resilience. The addition of warships involved in maintaining the border waters of Indonesia-Philippines is one of the efforts and agreements relating to the theory of Regional Stability proposed by Jhon Spanier, that "Stability of the region is an agreement among states about the differences between them with a view to maintaining the existing international system".

Likewise, increasing the number of warships involved in tackling piracy is consistent with the theory Trinity. This theory has been proposed by Kent Booth. In which the Navy must have a controlcapabilities of the SeaandSea denialin order to uphold state sovereignty at sea by means of state defense and deterrence, ward off any military threats by sea, and maintain regional security stability.

\section{c. Personnel Aspects.}

Decision of the naval forces involved in a maritime border patrol of Indonesia-Philippines in tackling piracy can not be determined by how many of its personnel but how a lot of power warships held. In accordance with the calculated analysis using the Coverage Area formula calculation, the number of Indonesian warships (KRI) involved in maintaining the Indonesian-Pilippine border is seven KRIs. The number of personnel will adjust to the number of warships involved, not the reverse number of KRI adjust the number of personnel. This is in accordance with Kent Booth's theory. This theory also justify strategic role of diplomacy and the using of the show of Naval Presence designed to influence the leadership of other countries or influence the leadership of the ASG no longer to commit the crime of piracy.

\section{d. Aspects of Base.}

Based on the Kent Booth theory of Naval Presence in which the Navy has the ability of sea control and sea denial, then this theory could be associated with the efforts of the Navy to build facilities and infrastructure (base for military operation), especially the Navy base in Bitung, Melonguane and Tahuna in addition to supporting the fight against piracy as well as efforts to build the capability of the operation of the elements of the Navy.

The presence of warships in the sea has its significance other than to implement the role of the military as a combat force, in an effort to enforce the law at sea as well as the role of diplomacy to support the government's foreign policy. Related Base as a support for the military power at the sea in particular must be supported by $4 \mathrm{R}$ (Reform/Refuel, Repair, Recreation and Rest) of warship. In this the construction of facilities and infrastructure Base is its part in order to enforce the state sovereignty at sea by way of state defense and deterrence, preparing the power for was preparation, ward off any military threats by sea, and maintain the security stability of theregion. At the same time the construction of thebase is part of the support of national stability and development. 


\section{e. Aspects of Operation Area.}

Navy operations must be supported by the ideal number of elements adapted to the length of border waters and bases, capable of supporting the resilience of operations. However, this is not yet a supported the concept. As the Patkor Philindo operation, the goal of Patkor cooperation is the realization of regional resilience proposed by Bantarto Bandoro and the theory of Regional Stability proposed by John Spanier. To reach an understanding of the operating area the Patkor Philindo cooperation must the Indonesia boundary line with the Philippines. It requires agreement from both countries including the agreement to use the power of rapid reaction unit in the event of piracy in the waters of Indonesia-Philippines border.

Figure 3:- Philindo \& Malphindo Operations Area Map

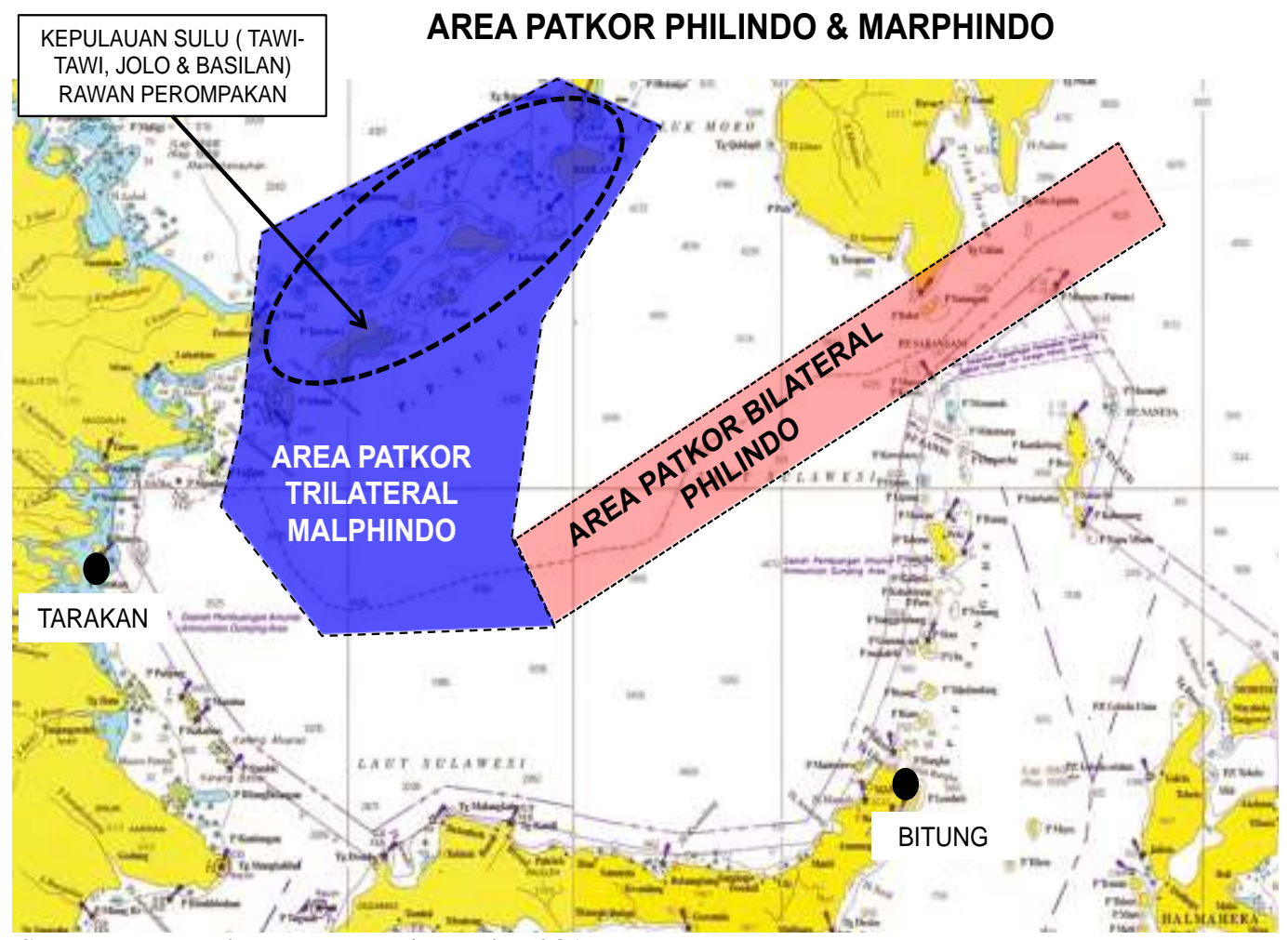

Source: Researchers Processed Results, 2017

\section{f. $\quad$ Aspect of Standard Operating Procedure (SOP).}

In accordance with the theory put forward by Sir Charles Hedges, that "pirates are robbers who seized the vessel and/or cargo through the hard way in the sea", the Crimes Pirate High Level (Major Criminal Hijack) and its group will take steps for a more organized. They will involve international organized crime which mobilize a group of trained people equipped with firearms, then in overcoming this piracy, it required a mechanism in the form of SOP. This SOP is used as a guide for executing elements in the field in implementing Patkor to overcome piracy in Indonesian border waters-Philippines.

Implementation of Standard Operating Procedure is needed in Patkor Philindo, because in the SOP it is set technically, starting from the planning stage, preparation, execution and termination. Some of the materials set forth in the SOP include: communication procedures, rules of engagement (Rule of Engagement - ROE), Hot Pursuit, information exchange procedures and intelligence data, hostage release procedures and others deemed necessary by both party.

\section{Aspects to be Considered in the Philippines-Indonesia in Cooperation.}

a. Increasing the Number of Allocations of Alutsista Involved.

1) Aspect Quantity.

Allocation element, i,e. the KRI involved in Patkor Philindo was minimal at only 1 KRI class Fast Patrol Boat (FPB) or KRI Class Parchim. Likewise, the Philippines Navy warship involves only 1 warship. This is in contrast 
with the extend and broad of the Indonesian-Philippines border water which stretching from the Western border around the island of Tawi-tawi and the Sulu island to the water of Davao Miangas, about $600 \mathrm{Nm}$.

It is therefore this writer will suggest that with such border area of Indonesia- Philippines, the number of KRI held in Patkor is as follows:

$$
\text { Number of vessels needed }(\mathrm{JK})=\text { Ability of the Ship }
$$

Seeking patrol boat capability (AP) is assumed:
a) The ability of radar detection (R)
$: 24 \mathrm{NM}$
b) Speed boat patrol (VS)
: 16 Knots
c) Target vessel speed (VW)
: 10 Knots
d) Length of territory
e) Area width
$: \mathrm{LP}=600 \mathrm{Nm}$
f) Patrol ability
Capability of patrol boat:

$$
\begin{aligned}
\mathrm{AP} & =\text { Length of region } \times \text { Area width } \\
\mathrm{LP} & =(\mathrm{VS} / \mathrm{VM} \times \mathrm{R})+2 \mathrm{R} \\
& =(16 / 10 \times 24)+(2 \times 24) \\
& =86.4 \mathrm{NM}
\end{aligned}
$$

Patrol ability $(\mathrm{AP})=$ Area length $\mathrm{x}$ Area width

$$
\begin{aligned}
\mathrm{AP} & =86.4 \mathrm{NM} \times 48 \mathrm{NM} \\
& =4,147.2 \mathrm{NM} \text { square }
\end{aligned}
$$

Number of vessels needed (JK)

$$
\begin{aligned}
\text { JK } & =\frac{\text { Area }}{\text { Puan patrol boat }} \\
& =28,800: 4,147.2 \\
= & 6.94=7 \mathrm{KRI}
\end{aligned}
$$

KRI element needed to carry out border patrol Indonesia-Philippines border which length about $600 \mathrm{Nm}$ is $7 \mathrm{KRI}$. Patkor Philindo has not involved the aircraft to conduct maritime patrols. This is due to the limitations of Pesud Patmar from the Philippines Navy.

\section{2) Quality Aspects.}

In general, when compared to the strength of the Philippines, the quality of the KRI (the Indonesian warships) involved in Patkor Pihilippine is much better than the Philippines warships, for example the technical ties of Philippines warships involved in Patkor Philippines 2015 namely BRP Cebu (PS-28) ${ }^{4}$, the condition is too old that only able to man-oeuvre with a maximum speed of 10 knots on calm sea conditions. Factor greatly and badly affect the KRI SRA- $802^{5}$ when executing Patkor as well as convoy for a long time as the specification of KRA SRA-802 booster engine can not be low speed in a long time.

\section{b. Personnel to Operate the Alistasista.}

Determination of the number of elements involved in securing the Indonesian-Philippines maritime border is not determined by the number of personnel, but is determined based on the number of vesels/KRI required to be faced with the area of the border area.

${ }^{4}$ BRP Cebu is one of the Philippines' naval patrol warships that are actively conducting coordinated patrols in Indonesian-Philippines border waters.

${ }^{5}$ KRI SRA-802 is an Indonesian Navy warship type of coastal patrol from Eastern Indonesia Fleet. 


\section{c. Base as a Supporting Element.}

The bases closest to the Indonesian-Philippines border region are Lanal Tahuna, Lanal Melonguane and Lantamal Manado. Liquid logistics needs especially HSD (diesel) can not be supported at Tahuna and Melonguane base because two bases are very limited availability of fuel to support KRI, so that fuel resupply can be done in Bitung North Sulawesi. Future challenges, sustainable development and supply infrastructure to support fuel re-stocking become a priority not only for the interests of the TNI/Navy but also for the benefit of the local community.

\section{d. Areas of Operation.}

Indonesian-Philippines maritime boundary line length is about $600 \mathrm{Nm}$, start from Westward around the island of Tawi-tawi, Sulu island up to the Eastern border area Miangas-Davao Island. However, the area of operation performed in Patkor Philindo is only 1/5 (one fifth) or about $120 \mathrm{Nm}$. This greatly affects the objectives achieved in implementing Patindo Philindo, not yet covering the border security around the highly vulnerable waters of piracy around Tawi-tawi waters-Sulu island and Basilan island.

\section{e. Standard Operating Procedure (SOP).}

There is no Standard Operating Procedures (SOP) Patkor Philindo so there is no definite guidance or reference that can be used as a reference for the implementation of

\section{d. Areas of Operation.}

Patkor. In addition it does not already have the SOP for the Navy of the two countries in securing the maritime border Indonesia-Philippines, it will cause misunderstanding in certain things, such as the concept of communication, the rules of engagement (Rules of Engagement), pursuit of cross limit (Cross border pursuit).

\section{Conclusion:-}

The joint and coordinated patrol cooperation between Indonesia-Philippines conducted annually by the Indonesian Navy with Republic Philippines Navy (RPN) is able to maintain good relations between the two countries. Border waters of Indonesia-Philippines-Malaysia especially around the waters of the Sulu islands are still vulnerable to the threat of piracy committed by the ASG group because there are still limitations, such as: (a). The allocation of forces involved in securing the Indonesian-Philippines border is not based on how large the number of personnel, but based on the allocation of warships (KRI) confronted with the border of Indonesia-Philippines border waters. (b). Area Operations carried out in Patkor Philindo currently around $120 \mathrm{Nm}$ (just $1 / 5$ of a length of approximately $600 \mathrm{Nm}$ maritime border between the two countries) have not m EMG cover the entire border p erairan In donesiaPhilippines. (c). Standard Operating Procedure - SOP is needed for the implementing element in the field, it will be used as a guide in carrying out Patkor in the border waters of Indonesia-Philippines.

Attempts to overcome the piracy committed by the US on the Sulu archipelago can not only be resolved bilaterally between Indonesia and the Philippines alone, but should be carried out jointly on a Trilateral, or multilaeral basis because of the location or the pirate base of the ASG is located around the Philippines-Malaysian-Indonesia border.

In order to maintain the stability of the region it is necessary to present the power of the Navy of three countries, namely the Indonesian Navy and the Republic of Philipine Navy to run an Air Force-powered Patkor Malphindo in tackling piracy in the Sulu waters, which is the basis of the ASG and is in the vicinity of the three-country border waters.

To expedite the implementation of Patkor Bilateral Philindo and Patkor Trilateral Malphindo, it is necessary to establish Standard Operating Procedure -SOP as guidance for military personel (the Navy and the warships) in the field in implementing existing bilateral cooperation Patkor Philindo to overcome the crime of piracy in the border waters of both countries.

There is a need for a strengthening the capacity and amount of the KRI involved in Patkor Philindo and Malphindo (if it has been formed) adapted to the area of operation, where the Indonesian-Philippines frontier of approximately $600 \mathrm{Nm}$ requires the ideal number of warships as many as seven warships as well as the duration of time in that Patkor is a year-round in order to minimize breaches of the international law at sea. 